\title{
BENTUK PERUSAHAAN JASA ANGKUTAN SEWA KHUSUS MENURUT PERATURAN MENTERI PERHUBUNGAN NOMOR 118 TAHUN 2018
}

\author{
Siti Mariyam*
}

\begin{abstract}
The industrial revolution 4.0 has influenced businesses in the field of trade in goods and services. In the trade of services, a new type of online rental service / taxi has emerged. Special leased transportation is a door-to-door transportation service with drivers who have operational areas in urban areas, from airports to airports, ports or other transportation nodes and reservations using information technology-based applications, with the tariff rates listed in the application. The implementation of this special rental transportation is based on the Regulation of the Minister of Transportation Number 118 of 2018 concerning the Implementation of Special Rental Transportation. To provide legal certainty on aspects of safety, security, comfort, equality, afford ability, and regularity for the community over the implementation of special rental transportation, and to support development to realize public welfare as mandated by the 1945 Constitution of the Republic of Indonesia.
\end{abstract}

Keywords: Companies, Services, Special Leased Transportation, Regulation of the Minister of Transportation Number 118 Year 2018

\section{PENDAHULUAN}

Perkembangan teknologi komunikasi, media dan informatika telah mengubah perilaku manusia di bidang ekonomi, sosial, budaya dan politik secara cepat dan signifikan. Kemajuan teknologi komunikasi, media dan informatika telah membuat perubahan di bidang Industri yang dikenal dengan Revolusi Industri 4.0 yaitu, sebuah Revolusi Industri 4.0 yang menggabungkan Cyber Physical Systems, Internet of things, Networks, pada era ini mulai ke dunia virtual. Pada era industri 4.0 sudah menggunakan robot-robot dan akan mengurangi pekerjaan manual manusia sehingga banyak lapangan pekerjaan yang berkurang dan berubah.

Peranan dan kedudukan tenaga kerja perlu ditingkatkan kualitas tenaga

\footnotetext{
* Siti Mariyam adalah Pengajar di Fakultas Hukum Universitas 17 Agustus 1945 Semarang dapat dihubungi melalui email : sitimariyam@untagsmg.ac.id
}

kerjanya dan peran sertanya dalam pembangunan untuk menghadapi Revolusi Industri 4.0. Tenaga kerja yang tidak memiliki pendidikan dan keahlian yang lebih tinggi serta pandangan virtual akan tergeser dengan robot-robot yang menggunakan Cyber Physical System dan Internet of Things, Network sehingga banyak pelayan-pelayan toko tidak punya pekerjaan karena tokonya tutup diganti dengan Shopee, Bukalapak, OLX, Tokopedia, Lazada, Blibli.com, sehingga mereka mencari pekerjaan lain.

Pengaruh industri 4.0 menyebabkan perubahan pada perdanganan, tidak hanya pada sektor perdagangan barang namun juga berpengaruh pada sektor perdagangan jasa. Salah satu usaha jasa yang lahir akibat dari perkembangan teknologi komunikasi, media dan informatika adalah usaha di bidang jasa angkutan yaitu munculnya taksi online/angkutan sewa khusus.

Transportasi online di Indonesia pertama kali hadir pada tahun 2015, 
ditandai dengan hadirnya taksi Uber, GoCar, dan Grab Car yang menimbulkan pro dan kontra di masyarakat. Bagi konsumen atau penumpang, taksi online memberikan manfaat berupa kemudahan dalam mengakses, murah dan nyaman. ${ }^{1}$ Adapun bagi pengemudi, taksi online dapat memberikan penghasilan tambahan yang dapat meningkatkan kesejahteraan keluarga. ${ }^{2}$ Sementara itu, bagi pelaku usaha taksi konvensional, muculnya taksi online menimbulkan kerugian karena mengurangi pangsa pasar yang berakibat turunnya pendapatan. ${ }^{3}$ Kemudahan dalam mengakses taksi online, menyebabkan taksi konvensional ditniggalkan oleh masyarakat. berikut perbedaan antara taksi konvensional dengan taksi online: ${ }^{4}$

1. Taksi konvensional terdaftar secara resmi di Dinas Perhubungan, sehingga berhak mendapat plat kuning tanda angkutan umum, sedangkan angkutan sewa khusus/taksi online menggunakan kendaraaan biasa yang bukan untuk angkutan umum.

2. Taksi konvensional sebagai angkutan umum, berkewajiban membayar pajak yang besarnya berbeda dengan kendaraan plat hitan yang digunakan oleh angkutan sewa khusus/taksi online.

3. Taksi konvensional menggunakan metoda menunggu penumpang, sedangkan angkutan sewa khusus menjemput penumpag.

4. Tarif taksi konvensional lebih mahal jika dibandingkan dengan angkutan sewa khusus.

1 Wawancara dengan Anti, penumpang Taksi Online, di kota Semarang, tanggal 12 November 2018.

2 Wawancara dengan Bambang, pengemudi Taksi Online di kota Semarang, tanggal 5 Oktober 2018.

3 Wawancara dengan Widodo, pengemudi Taksi Konvensional di kota Semarang, 1 Oktober 2018.

4 Direktori Putusan Mahkamah Agung Republik Indonesia Nomor 37/P/HUM/2017, Jakarta, Hlm. 15.
Kehadiran taksi online memberi banyak pilihan angkutan pada penumpang. Taksi online semakin banyak dipilih dan digunakan oleh penumpang dengan alasan mudah diunduh, murah, aman dan nyaman dibandingkan dengan taksi konvensional. ${ }^{5}$

Taksi online diatur dalam Peraturan Menteri Perhubungan Nomor 118 Tahun 2018 tentang Penyelenggaraan Angkutan Sewa Khusus. Peraturan Menteri ini dimaksudkan sebagai pedoman dalam penyelanggaraan angkutan sewa khsusus.

Pasal 3 sampai dengan Pasal 6, memuat ketentuan kriteria pelayanan angkutan sewa khusus. Pasal 3 ayat (1) menyatakan, pelayanan angkutan sewa khusus harus memenuhi kriteria pelayanan sebagai berikut:

a. Wilayah operasi berada di dalam kawasan perkotaan, dan dari dan ke badar udara, pelabuhan, atau simpul transportasi lainnya;

b. Tidak berjadwal;

c. Pelayanan dari pintu ke pintu;

d. Tujuan perjalanan ditentukan oleh pengguna jasa;

e. Besaran tarif angkutan tercantum pada aplikasi berbais teknologi informasi;

f. Memenuhi standar pelayanan minimal; dan

g. Pemesanan dilakukan melalui aplikasi berbasis teknologi informasi.

Adapun pengusahaan angkutan sewa khusus diatur dalam Pasal 11 sampai dengan Pasal 20 Permenhub. Nomor 118 Tahun 2018. Menurut ketentuan Pasal 11, perusahaan angkutan sewa khusus wajib memiliki izin penyelenggaraan angkutan sewa khusus, namun realitanya para pelaku usaha/pengemudi angkutan sewa khusus

5 Hasil survey online yang dilakukan oleh Yayasan Lembaga Konsumen Indonesia (YLKI) yang dilaksanakan pada tangal 5-16 April 2017 yang melibatkan 4.668 responden. Hasil survey tersebut mengatakan, bahwa alasan utama responden memilih menggunakan transportasi online adalah: murah $(84,1$ persen), cepat $(81,9$ persen), nyaman (78,8 persen) dan aman $(61,4$ persen). 
bersifat individual/perorangan dan tidak mempunyai izin sebagai penyelenggara angkutan sewa khusus yang bekerjasama dengan perusahaan aplikasi.

Berdasar uraian latar belakang tersebut di atas maka dapat dirumuskan permasalahan bagaimana bentuk perusahaan angkutan sewa khusus menurut Peraturan Menteri Perhunungan Nomor 118 tahun $2018 ?$

\section{PEMBAHASAN}

Pengangkutan merupakan bagian dari masyarakat. bagi dunia usaha, pengangkutan berperan penting dalam mendukung proses produksi dan distribusi barang dan/atau jasa. Bagi masyarakat sebagai pengguna jasa / konsumen, pengangkutan menjadi bagian dari kegiatan konsumsi, dengan demikian pengangkutan berfungsi penting dalam perkembangan masyarakat.

Fungsi pengangkutan adalah memindahkan barang atau orang dari satu tempat ke tempat lain dengan maksud untuk meningkatkan daya guna dan nilai. ${ }^{6}$ Menurut Abdul Kadir Muhammad, ${ }^{7}$ konsep pengangkutan meliputi 3 (tiga) aspek yaitu:

1. Pengangkutan sebagai usaha (business);

2. Pengangkutan sebagai perjanjian; dan

3. Pengangkutan sebagai proses (applying process).

Pengangkutan sebagai usaha (business) mempunyai ciri-ciri yaitu berdasarkan perjanjian, kegiatan ekonomi di bidang jasa, berbentuk perusahaan, dan menggunkan alat angkut mekanik. Pengangkutan sebagai perjanjian pada umumnya bersifat lisan (tidak tertulis) tetapi selalu didukung oleh dokumen perjanjian. Perjanjian pengangkutan dapat juga tertulis yang disebut perjanjian carter.

6 H.M.N. Purwosutjipto dalam Andika Wijaya, ibid, Hlm. 169.

7 Abdul Kadir Muhammad, 2013, Hukum Pengangkutan Niaga, Bandung, Citra Aditya Bakti, Hlm. 1.
Adapun perjanjian sebagai proses yaitu serangkaian perbuatan mulai dari pemuatan ke dalam alat pengangkut, kemudian dibawa menuju ke tempat yang telah ditentukan, dan pembongkaran atau penurunan di tempat tujuan. ${ }^{8}$

Istilah pengangkutan biasa pula disebut dengan transportasi terjemahan kata dalam bahasa Inggris transportation. Pengangkutan lebih menekankan pada aspek yuridis sedangkan transportasi lebih menekankan pada aspek kegiatan perekonomian, akan tetapi keduanya memiliki makna yang sama, yaitu sebagai kegiatan pemindahan dengan mengguna kan alat angkut.'

Istilah pengangkutan tidak dijumpai dalam Undang-undang Nomor 22 Tahun 2009 . Dalam Undang-undang menggunakan istilah angkutan. Pengertian angkutan menurut Pasal 1 angka (3) Undang-undang Nomor 22 tahun 2009 adalah perpindahan orang dan/atau barang dari satu tempat ke tempat lain dengan menggunkan kendaraan di ruang lalu lintas jalan. Ruang lalu lintas jalan adalah prasarana yang diperuntukkan bagi gerak pindah kendaraan, orang, dan/atau barang yang berupa jalan dan fasilitas pendukung (Pasal 1 angka (11) Undang-Undang Nomor 22 Tahun 2009). Kendaraan menurut Pasal 1 angka (7), adalah suatu sarana angkut di jalan yang terdiri atas kendaraan bermotor dan kendaraan tidak bermotor.

Di dalam Pasal 137 Undang-undang Nomor 22 Tahun 2009 menyebutkan bahwa angkutan orang dan/atau barang dapat menggunakan kendaraan bermotor dan kendaraan tidak bermotor. Angkutan orang yang menggunakan kendaraan bermotor berupa sepeda motor, mobil penupang, atau bus.

8 Abdulkadir Muhammad, 1998, Hukum Pengangkutan Niaga, Bandung, Citra Aditya bakti, Hlm. $12-13$.

9 Melkianus E,N, 2015, Hukum pengangkutan, Transportasi, meongmoo. Blogspot, diakkses tanggal 8 Juli 2019. 
Fungsi pengangkutan adalah memindahkan barang atau orang dari satu tempat ke tempat lain dengan maksud untuk meningkatkan daya guna dan nilai. ${ }^{10}$ Menurut Abdul Kadir Muhammad, ${ }^{11}$ konsep pengangkutan meliputi 3 (tiga) aspek yaitu:

1. Pengangkutan sebagai usaha (business);

2. Pengangkutan sebagai perjanjian; dan

3. Pengangkutan sebagai proses (applying process).

Pengangkutan sebagai usaha (business) mempunyai ciri-ciri yaitu berdasarkan perjanjian, kegiatan ekonomi di bidang jasa, berbentuk perusahaan, dan menggunkan alat angkut mekanik. Pengangkutan sebagai perjanjian pada umumnya bersifat lisan (tidak tertulis) tetapi selalu didukung oleh dokumen perjanjian. Perjanjian pengangkutan dapat juga tertulis yang disebut perjanjian carter. Adapun pengangkutan sebagai proses yaitu serangkaian perbuatan mulai dari pemuatan ke dalam alat pengangkut, kemudian dibawa menuju ke tempat yang telah ditentukan, dan pembongkaran atau penurunan di tempat tujuan. ${ }^{12}$

Pengusahaan angkutan sewa khusus diatur dalam Pasal 11 sampai dengan Pasal 20 Permenhub. Nomor 118 Tahun 2018. Menurut ketentuan Pasal 11, perusahaan angkutan sewa khusus wajib memiliki izin penyelenggaraan angkutan sewa khusus. Izin penyelenggaraan angkutan sewa khusus dikenakan biaya sebagai penerimaan negara bukan pajak atau retrubusi daerah.

Di dalam Pasal 12 menyatakan bahwa, perusahaan angkutan sewa khusus harus berbentuk badan hukum Indonesia. Badan hukum Indonesia tersebut berbentuk Badan Usaha Milik Negara (BUMN), Badan Usaha Milik Daerah (BUMD),

10 H.M.N. Purwosutjipto dalam Andika Wijaya, Op. Cit, Hlm. 169.

11 Abdul Kadir Muhammad, Op Cit Hlm. 1.

12 Abdulkadir Muhammad, Op. Cit, Hlm. 12-13.
Perseroan Terbatas (PT), dan Koperasi. Selain badan hukum tersebut di atas, penyelenggaraan angkutan sewa khusus dapat dilakukan oleh pelaku usaha mikro atau pelaku usaha kecil.

Ketentuan badan hukum bagi perusahaan taksi online / angkutan sewa khusus sesuai dengan amanat Pasal 139 ayat (4) Undang-Undang Nomor 22 Tahun 2009 Tentang Lalu Lintas dan Angkutan Jalan, dan Pasal 79 PP Nomor 74 Tahun 2014 Tentang Angkutan Jalan, yaitu berbentuk Badan Usaha Milik Negara, Badan Usaha Milik Daerah, Perseroan Terbatas, dan Koperasi.

Jika perusahaan angkutan sewa khusus berbentuk badan usaha Perseroan Terbatas maka tunduk pada UndangUndang Nomor 40 Tahun 2007 tentang Perseroan Terbatas, namun bila berbentuk Badan Usaha Milik Negara dan Badan Usaha Milik Daerah tunduk pada UndangUndang Nomor 19 Tahun 2003 tentang Badan Usaha Milik Negara dan juga Undang-Undang Nomor 40 Tahun 2007. Jika berbadan hukum Koperasi maka mengikuti ketentuan dalam UndangUndang Nomor 25 Tahun 1992 Tentang Perkoperasian.

Selain berbentuk badan hukum Indonesia, taksi online dapat juga berbentuk pelaku usaha mikro dan pelaku usaha kecil. Apabila berbentuk usaha mikro dan usaha kecil maka berlaku ketentuan Undang-Undang Nomor 20 Tahun 2008 Tentang Usaha Mikro, Kecil, dan Menengah (UMKM). Bentuk usaha UMKM diakui dalam Permenhub. Nomor 118 Tahun 2018, sesuai dengan dasar pertimbangan Mahkamah Agung dalam Putusan Nomor $15 \mathrm{P} / \mathrm{HUM} / 2017$, yaitu guna mendorong dan memajukan Usaha Mikro, Kecil, dan menengah (UMKM), maka penyelenggara taksi online dapat dilakukan oleh pelaku usaha mikro atau pelaku usaha kecil, hal ini sesuai dengan amanat Undang-Undang Nomor 20 tahun 2008 Tentang UMKM. 
Permohonan izin penyelenggaraan angkutan sewa khusus, menurut Pasal 13, dapat berupa:

1. Izin bagi pemohon baru;

2. Pembaruan masa berlaku izin penyelenggaraan angkutan sewa khusus dan/atau

3. kartu elektronik Standar Pelayanan.

4. Perubahan dokumen izin, terdiri atas:

a. Penambahan kendaraan;

b. Penggantian dokumen perizinan yang hilang atau rusak;

c. Perubahan identitas perusahaan angkutan sewa khusus; dan atau

d. Penggantian kendaraan atau peremajaan kendaraan; dan/atau

5. Pembukaan cabang perusahaan angkutan sewa khusus.

Izin penyelenggaraan angkutan sewa khusus berlaku selama perusahaan angkutan sewa khusus menjalankan usahanya dan tidak mengalami perubahan dokumen izin. Permohonan izin penyelenggaraan angkutan sewa khusus menggunakan format dan formulir sesuai yang tercantum dalam lampiran II Permenhub. Nomor 118 Tahun 2018.

Adapun permohonan izin penyelenggaraan angkutan sewa khusus mengikuti mekanisme yang diatur dalam peraturan perundang-undangan mengenai pelayanan perizinan berusaha terintegrasi secara elektronik atau Online Single Submission (OSS).

Pelayanan perizinan berusaha terintegrasi secara elektronik atau Online Single Submission (OSS) diatur dalam Peraturan Pemerintah (PP) Nomor 24 Tahun 2018 Tentang Pelayanan Perizinan berusaha Terintegrasi Secara Elektronik. Perizinan berusaha terintegrasi secara elektronik atau Online System Submission (OSS) adalah perizinan berusaha yang diterbitkan oleh lembaga OSS untuk dan atas nama Menteri, Pimpinan Lembaga, Gubernur, atau Bupati/Wali Kota kepada pelaku usaha melalui sistem elektronik yang terintegrasi. OSS diterapkan dalam rangka percepatan dan peningkatan penanaman modal dan berusaha perlu menerapkan pelayanan perizinan berusaha terintegrasi secara elektronik.

Perusahaan angkutan sewa khusus merupakan subjek hukum. Pemahaman terhadap subjek hukum tidak terlepas dari pemahaman terhadap orang (persoon). Sebagaimana dikatakan oleh Subekti, perkataan orang (persoon) berarti pembawa hak atau subjek di dalam hukum ${ }^{13}$ dalam konteks hukum perdata menurut KUHPerdata, persoalan subjek hukum dibahas dalam hukum tersendiri yang bernama hukum orang. Mengutip pendapat Subekti, hukum orang adalah peraturan tentang manusia sebagai subjek dalam hukum, peraturan perihal kecakapan untuk memiliki hak dan kecakapan untuk bertindak sendiri melaksanakan haknya itu serta hal yang mempengaruhi kecakapan itu. ${ }^{14}$ Berdasarkan pendapat Subekti tersebut, yang dimaksud subjek hukum adalah pembawa hak.

Secara garis besar ilu pengetahuan hukum perdata membagi subjek hukum atau pembawa hak menjadi 2 (dua) pihak, yakni manusia naturalijke persoon dan adan hukum (recht persoon). Badan hukum dapat memiliki hak dan bisa melakukan perbuatan hukum seperti seorang manusia, badan hukum mempunyai kekayaan sendiri, serta ikut dalam lalu lintas hukum dengan perantaraan pengurusnya, dapat digugat dan dapat juga menggugat di muka hakim. ${ }^{15}$ Contoh dari badan hukum adalah Perseroan tebatas dan Koperasi.

Subjek hukum adalah pembawa hak atau subjek dalam hukum. Hakekat dari tranportasi jalan online khususnya taksi online seperti misalnya, Uber, Go-Car, Grab Car adalah memberikan pelayanan atau jasa angkutan kepada seluruh masyarakat. menjaring pelanggan seluas-

\footnotetext{
13 Subekti, 1987, Pokok-Pokok Hukum Perdata, Jakarta, Intermasa, Hlm. 19

14 Ibid, Hlm. 16

15 Ibid, Hm. 21.
} 
luasnya dari masyarakat merupakan target dari perusahaan.

Menurut Andika Wijaya dalam bukunya Aspek Hukum Bisnis Transportasi Jalan Online, ${ }^{16}$ realisasi usaha transportasi yang dilakukan oleh perusahaan transportasi jalan online memunculkan suatu perikatan hukum dengan pelanggan (customer). Dalam hal ini, perusahaan transportasi jalan online mengadakan transaksi berupa perjanjian pemberan jasa transportasi, transaksi mana dilakukan melalui metode elektronik, yang memunculkan hak dan kewajiban bagi kedua belah pihak. Perusahaan transportasi jalan online memberikan hak kepada pelanggan (customer) atas layanan atau jasa transportasi tertentu, dan di lain pihak memunculkan hak atas imbalan atau tarif bagi perusahaan pengangkutan jalan online. Perusahaan transportasi jalan online melakukan kewajibannya berupa pemberian jasa atau layanan transportasi, sedangkan kewajiban pihak pelanggan (customer) membayar ongkos layanan (tarif) dengan nilai tertentu kepada perusahaan transportasi jalan online.

Hak dan kewajiban yang muncul dari perjanjian penggunaan jasa taksi online merupakan obyek hukum. Subjek hukumnya ada 2 (dua) yakni, perusahaan angkutan taksi online dan pelanggan/ penumpang. Perusahaan taksi online di satu sisi, dan pelanggan di sisi lain, masingmasing berkedudukan sebagai pembawa hak. Kedudukan perusahaan taksi online sebagai subjek hukum tidak terbatas adanya hubungan hukum dengan penumpang, namun juga berkedudukan sebagai subjek hukum ketika perusahaan mengadakan perjanjian kemitraan dengan perusahaan aplikasi.

Pada dasarnya peraturan mengenai bentuk perusahaan angkutan tunduk pada Undang-Undang Nomor 22 Tahun 2009

16 Andika Wijaya, 2016, Aspek Hukum Bisnis Transportasi Jalan Online, Jakarta, Sinar Grafika., Hlm 33-34 serta peraturan pelaksananya Peraturan Pemerintah (PP) Nomor 74 tahun 2014 Tentang Angkutan Jalan. Pasal 79 PP Nomor 74 tahun 2014 menetukan bahwa perusahaan angkutan umum yang menyelenggarakan angkutan orang dan/atau barang harus berbentuk badan hukum Indonesia sesuai dengan ketentuan peraturan perundang-undangan. Pasal 79 ayat (2) PP Nomor 74 tahun 2014 menjelaskan lebih lanjut bahwa badan hukum Indonesia yang merupakan perusahaan angkutan umum yang menyelenggarakan angkutan orang dan/atau barang harus berbentuk:

1. Badan Usaha Milik Negara;

2. Badan Usaha Milik Daerah;

3. Perseroan Terbatas; atau

4. Koperasi.

Ketentuan perusahaan angkutan taksi online/angkutan sewa khusus dapat dilihat dalam ketentuan Pasal 12 Permenhub Nomor 118 tahun 20118 Tentang Angkutan Sewa Khusus, perusahaan angkutan sewa khusus harus berbentuk badan hukum Indonesia sesuai peraturan perundang-undangan. Badan hukum Indonesia tersebut berbentuk: Badan Usaha Milik Negara, Badan Usaha Milik Daerah, Perseroan Terbatas, atau Koperasi. Di dalam Pasal 12 ayat (3) menyatakan, selain badan hukum Indonesia, penyelenggaraan angkutan sewa khusus dapat dilakukan oleh pelaku usaha mikro atau pelaku usaha kecil sesuai ketentuan peraturan perundang-undangan.

Sebagaimana ketentuan Pasal 12 ayat (2) dan ayat (3) Permenhub. Nomor 118 tahun 2018 adalah badan hukum swasta Indonesia yang diperkenankan menjadi perusahaan angkutan umum hanya terbatas pada yang berbentuk Perseroan Terbatas (PT) (yang dibentuk sesuai dengan Undang-Undang Nomor 40 Tahun 2005 Tentang Perseroan Terbatas) dan Koperasi (yang dibentuk berdasarkan undangundang Nomor 25 tahun 1992 Tentang Perkoperasian) bergerak di bidang 
penyelenggaraan angkutan umum.

Perusahaan taksi online atau angkutan sewa khusus adalah perusahaan angkutan orang dengan kendaraan bermotor umum berbasis teknologi informasi yang berbentuk badan hukum atau pelaku usaha mikro atau pelaku usaha kecil yang menyelenggarakan jasa angkutan sewa khusus.

Realitas yang ada di masyarakat, pelaku usaha/pengemudi taksi online mengajukan permohonan aplikasi ke perusahaan aplikasi seperti Go-Jek, Grab, maupun Uber tidak berbentuk badan hukum maupun koperasi namun perorangan yang belum memiliki izin penyelenggaraan angkutan. Demikian ini dapat dilihat dari persyaratan permohonan aplikasi yang diumumkan oleh perusahaan aplikasi.

Pendaftaran bagi pengemudi taksi online pada perusahaan aplikasi GO-Jek, Grab, maupun Uber dapat dilakukan secara offline dan Online. Pendaftaran secara offline dilakukan dengan cara datang secara langsung ke kantor perusahaan aplikasi tersebut, sedangkan pendaftaran calon pengemudi taksi online dilakukan secara offline maupun online. persyaratan pendaftaran terbagi menjadi 2 (dua) yaitu persyaratan untuk calon pengemudi dan persyaratan untuk mobil. ${ }^{17}$

1. Persyaratan untuk calon pengemudi.

Persayaratan yang harus dipenuhi bagi calon pengemudi adalah sebagai berikut:

a. Foto selfie setengah badan, muka terlihat jelas.

b. Memiliki SIM A atau SIM B1, SIM harus masih berlaku minimal 6 bulan.

c. Memiliki SKCK yang masih aktif.

d. Memilik nomor telepon yang mudah dihubungi.

$17 \mathrm{https}$ ://www.infojek.com/cara-mendaftardriver-go-car 2019. Cara mendaftar Driver Go Car 2019 Terbaru dan terlengkap, diunduh tanggal 12 Agustus 2019. e. Memiliki Smartphone android yang sudah diinstall aplikasi perusahaan aplikasi (Misal Go-Car) Driver.

f. Memiliki Email Gmail yang aktif.

g. Memiliki rekening Bank (BCA, Mandiri, CIMB, BNI, dll).

2. Persyaratan untuk mobil

Persyaratan bagi mobil yang mau digunakan untuk layanan adalah sebagai berikut:

a. Tahun produksi mobil keluaran 2012 ke atas.

b. Semua jenis mobil berpenumpang bisa digunakan untuk taksi online, seperti SUV, MPV, Coupe, Convertible, Crossover, Hatchback, dan lainnya.

c. Mobil harus memiliki kapasitas mesin di atas $1000 \mathrm{cc}$.

d. Foto mobil dengan nomor polisi yang terlihat.

e. Foto STNK yang jelas pada bagian depan dan belakang, keduanya diedit menjadi satu dengan posisi yang berjejer.

f. Memiliki asurans Allrisk, dibukti kan dengan polis asuransi.

g. KIR yang bersifat opsional, kadang dibutuhkan dan terkadang tidak, sesuai kebutuhan.

h. Surat domisili apabila nomor plat mobil berbeda dengan area calon pengemudi.

i. Surat balik nama (bersifat opsional, jika ada).

Persyaratan meliputi persyaratan pengemudi dan persyaratan bagi mobil ini dimaksudkan untuk memberikan perlindungan kepada penumpang terhadap aspek keselamatan, keamanan dan kenyamanan dalam menggunakan angkutan.

Persyaratan bagi pengemudi, dimaksudkan bahwa seorang pengemudi taksi online telah memiliki legalitas sebagai pengemudi dibuktikan dengan dimilikinya Surat Izin Mengemudi. Persyaratan ini sesuai dengan ketentuan Pasal 77 Undang- 
Undang Nomor 22 tahun 2009, bahwa setiap orang yang mengemudikan kendaraan bermotor di jalan wajib memiliki Surat Izin Mengemudi sesuai dengan jenis kendaraan bermotor yang dikemudikan. Surat mengemudi terdiri dari dua jenis yaitu: surat Izin Mengemudi kendaraan bermotor perorangan dan Surat Izin Mengemudi kendaraan bermotor umum.

Surat Izin Mengemudi (SIM) untuk kendaraan bermotor perseorangan menurut Pasal 80 Undang-Undang Nomor 22 Tahun 2009 digolongkan menjadi:

1. SIM A berlaku untuk mengemudikan mobil penumpang dan barang perorangan dengan jumlah berat yang diperbolehkan tidak melebihi 3.500 (tiga ribu lima ratus) kilogram.

2. SIM B I berlaku untuk mengemudikan mobil penumpang dan barang perorangan dengan jumlah berat yang diperbolehkan lebih dari 3.500 (tiga ribu lima ratus) kilogram.

3. SIM B II berlaku untuk mengemudikan kendaraan alat berat, kendaraan penarik atau kendaraan bermotor dengan menarik kereta tempelan atau gandengan perseorangan dengan berat yang diperbolehkan untuk kereta tempelan atau gandengan lebih dari 1.000 (seribu) kilogram.

4. SIM C berlaku untuk mengemudikan sepeda otor.

5. SIM D berlaku untuk mengemudikan kendaraan khusus bagi penyandang cacat.

Untuk mendapatkan Surat Izin Mengemudi, setiap orang harus memenuhi persyaratan usia, administratif, kesehatan dan lulus ujian. Surat Izin Mengemudi mempunyai fungsi sebagai:

a. Bukti kompetensi mengemudi,

b. Registrasi pengemudi kendaraan bermotor yang memuat keterangan identitas lengkap pengemudi

Data pada registrasi pengemudi dapat digunakan untuk mendukung kegiatan penyelidikan, penyidikan, dan identifikasi forensik kepolisian.

Hubungannya dengan persyaratan pengemudi taksi online/angkutan sewa khusus, seorang pengemudi harus memiliki SIM A atau SIM BI adalah untuk memberikan kepastian hukum bahwa pengemudi angkutan sewa khusus mempunyai kompetensi mengemudikan mobil penumpang. Legalitas ini diperlukan untuk terwujudnya pelayanan angkutan yang aman, selamat dan nyaman.

Persyaratan pendaftaran pengemudi taksi online tersebut di atas berlaku hingga sekarang. Perusahaan aplikasi masih menerima pengemudi taksi online yang bersifat individual dan tidak memiliki izin perusahaan angkutan. Demikian ini, bertentangan dengan Permenhub. Nomor 118 tahun 2018, bahwa taksi online/angkutan sewa khusus adalah perusahaan angkutan orang dengan kendaraan bermotor umum berbasis teknologi informasi yang berbentuk badan hukum atau pelaku usaha mikro atau pelaku usaha kecil yang menyelenggarakan jasa angkutan sewa khusus.

Adapun persyaratan mobil, dimaksudkan untuk memberikan perlindungan akan keselamatan, keamanan dan kenyamanan maka mobil harus laik jalan. Persyaratan laik jalan ini sebagaimana disyaratkan dalam Pasal 48 Undang-Undang Nomor 22 tahun 2009, yaitu setiap kendaraan bermotor yang dioperasikan di jalan harus memenuhi persyaratan teknis dan laik jalan. Persyaratan teknis terdiri atas:

1. Susunan;

2. Perlengkapan;

3. Ukuran;

4. Karoseri;

5. Rancangan teknis kendaraan sesuai dengan peruntukannya;

6. Pemuatan;

7. Penggunaan;

8. Penggandengan kendaraan bermotor; dan atau

9. Penempelan kendaraan bermotor. 
Persyaratan laik jalan ditentukan oleh kinerja minimal kendaran bermotor yang diukur sekurang-kurangnya terdiri atas:

1. Emisi gas buang;

2. Kebisingan suara;

3. Efisiensi sistem rem utama;

4. Efisiensi sistem rem parkir;

5. Kincup roda depan;

6. Suaraklakson;

7. Daya pancar dan arah sinar lampu utama;

8. Radius putar;

9. Akurasi alat penunjuk kecepatan;

10. Kesesuaian kinerja roda dan kondisi ban; dan

11. Kesesuaian daya mesin penggerak terhadap berat kendaraan.

Di dalam persyaratan mobil untuk dapat digunakan sebagai angkutan sewa khusus disayaratkan mobil dengan tahun produksi keluaran minimal tahun 2012, dimaksudkan kondisi mobil masih laik jalan. Keadaan mobil yang masih laik jalan, menurut ketentuan Permenhub. Nomor 118 Tahun 2018 Tentang Angkutan Sewa Khusus, mobil tidak harus menjalani uji KIR. Sebagai perusahaan angkutan umum, angkutan sewa khusus wajib mengurus perizinan ke Dinas Perhubungan.

Kewajiban terhadap pegurusan izin penyelenggara ini, Permenhub. Nomor 118 tahun 2018 dala ketentuan peralihan memberikan waktu kepada para pelaku usaha angkutan sewa khusus untuk menyesuaikan. Hal ini mengingat Peraturan Menteri Perhubungan Nomor 118 Tahun 2018 baru efektif berlaku tanggal 18 Juli 2019 dan dalam Pasal 44, memberi kesempatan kepada pemerintah pusat, pemerintah daerah, perusahaaan angkutan sewa khusus, dan perusahaan aplikasi wajib menyesuikan dalam jangka waktu paling lambat 6 (enam) bulan sejak tanggal Peraturan Menteri diundangkan.

\section{Kesimpulan}

Untuk memberikan kepastian hukum kepada masyarakat terhadap aspek keselamatan, keamanan, kenyamanan, kesetaraan, keterjangkauan, dan ketarauran dalam penyelenggaraan angkutan sewa khusus, maka berdasarkan Pasal 11 Peraturan Menteri Perhubiungan Nomor 118 Tahun 2018 Tentang Penyelenggaraan Angkutan Sewa Khusus, perusahaan angkutan sewa khusus wajib memiliki izin penyelenggaraan angkutan sewa khusus, dengan berbentuk badan hukum yaitu Badan Usaha Milik Negara, Badan Usaha Milik daerah, Perseroan Terbatas, dan Perseroan Terbatas, serta pelaku usaha mikro dan pelaku usaha kecil.

\section{Daftar Pustaka}

Abdulkadir Muhammad, 1998, Hukum Pengangkutan Niaga, Bandung, Citra Aditya Bakti.

Abdulkadir Muhammad, 1998, Hukum Pengangkutan Niaga, Bandung, Citra Aditya Bakti.

Abdul Djamali,2001, Pengantar Hukum Indonesia, Edisi 2 Cetakan 7, Jakarta, RajaGrafindo Persada.

A Mukti Fajar, 2016, Teori-Teori Hukum Kontemporer, Edisi Revisi, Malang, Setara Press.

Ahmad M. Ramli, 2006, Cyberlaw dan HAKI Dalam Sistem Hukum Indonesia, Bandung, PT Refika Aditama.

Ahmad Yani dan Gunawan Widjaya, Seri Hukum Bisnis: Anti Monopoli, Jakarta, RajaGrafindo Persada.

Andika Wijaya, 2016, Aspek Hukum Bisnis Transportasi Jalan Online, Jakarta, Sinar Grafika

Edy Santoso, 2018, Pengaruh Globalisasi Terhadap Hukum Bisnis Di Indonesia, Jakarta Timur, Kencana.

Esmi Warassih, 2005, Pranata Hukum Sebuah Telaah Sosiologis, Semarang, Suryandaru. 
Etta Mamang Sangadji dan Sopiah, 2013, Perilaku Konsumen: Pendekatan Praktis Disertai Himpunan Jurnal Penelitian, Yogyakarta, Andi Offset.

Subekti, 1985, Hukum Perjanjian, Jakarta, Intermasa. ..,1987, Pokok-Pokok Hukum Perdata, Jakarta, Intermasa. , 2002, Hukum Perjanjian, Jakarta, Intermasa.

Subekti dan Tjitrosudibio, 2001, Kitab Undang-Undang Hukum Perdata, Cetakan Ketiga Puluh, Jakarta, Pradnya Paramitra.

Undang-undang Nomor 11 Tahun 2008 Tentang Informasi dan Transaksi Elektronik.

Undang-Undang Nomor 22 Tahun 2009 Tentang lalu Lintas dan Angkutan Jalan.

Peraturan Pemerintah Negara Republik Indonesia Nomor 82 Tahun 2012 Tentang Penyelenggaraan Sistem dan transaksi Elektronik.
Peraturan Pemerintah Republik Indonesia Nomor 74 Tahun 2014 tentang Penyelenggaraan Angkutan Umum.

Peraturan Menteri Perhubungan Nomor 118 Tahun 2018 Tentang Penyelenggaraan Angkutan Sewa Khusus.

Putusan Mahkamah Agung Republik Indonesia Nomor 37/P/HUM/2017

https://www.infojek.com/cara-mendaftardriver-go-car 2019. Cara mendaftar Driver Go Car 2019 Terbaru dan terlengkap, diunduh tanggal 12 Agustus 2019.

Melkianus E, N, 2015 , Hukum pengangkutan, Transportasi, meongmoo. Blogspot, diakkses tanggal 8 Juli 2019 